CURRENT RESEARCH JOURNAL OF HISTORY

(ISSN -2767-472X)

VOLUME 03 ISSUE 01 Pages: 30-33

SJIF IMPACT FACTOR (2021: 5. 505)

OCLC - 1243560778 METADATA IF - 6.458

Crossref do

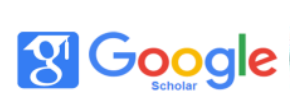

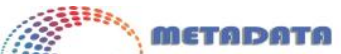

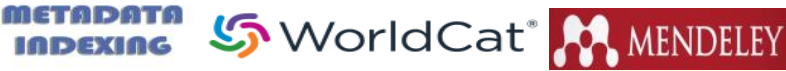

Publisher: Master Journals

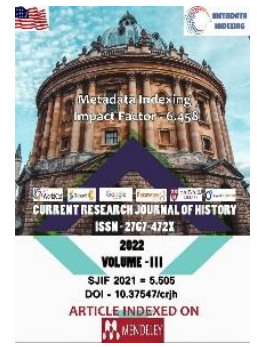

Journal Website: https://masterjournals. com/index.php/crih

Copyright: Original content from this work may be used under the terms of the creative commons attributes 4.0 licence.
Research Article

\section{FROM THE HISTORY OF THE JIZZAKH OASIS PRESS (THE ROLE OF INTELLECTUALS IN THE FORMATION AND DEVELOPMENT OF THE NEWSPAPER “JIZZAKH OVOZI”)}

\author{
Submission Date: January 09, 2022, Accepted Date: January 19, 2022, \\ Published Date: January 29, 2022 \\ Crossref doi: https://doi.org/10.37547/history-crih-03-01-07 \\ Khurshid O. Egamkulov \\ Lecturer, Independent Researcher, 21st Comprehensive School in Jizzakh, Uzbekistan
}

\title{
ABSTRACT
}

Usually, when we talk about the present and future of an industry, we look at, analyze and study the origins, formation and development of the industry, the activities of dedicated people who have contributed to the development of this industry and left a rich experience.

Therefore, when we talk about journalism, which is described as a "Mirror of life", including the press and journalism of the Jizzakh oasis, we first look at the history of the oasis, the way of life, culture, traditions and at a certain stage of development, we found it necessary to look at the reasons for the penetration of the press in the political, economic, cultural and educational life of the oasis, the process of its emergence, formation, development, as well as the activities of our compatriots who created a unique school with their talent, enthusiasm and dedication.

\section{KEYWORDS}

Journalism, press, newspaper, magazine, Jizzakh district, “Zarafshan ovozi”, “Jizzakh ovozi”, “Socialism galabasi”, printing house, correspondent. 


\section{INTRODUCTION}

It is not secret that in a certain period of historical development of human society, the need for analysis and criticism, propaganda and agitation, information and innovation, the emergence of the press in the political and economic, cultural and educational processes in the world and on its own soil. If we look at history, we can see that this process took place in our oasis in the early twentieth century. Although Achil Qori, Mirziyo Qori Mirabdulla, Sadriddin Mahsum and other compatriots took an active part in the enlightenment movement in Turkestan, which was left out of universal development due to the effects of the Tsarist colony, no separate press release has been published so far.

\section{THE MAIN RESULTS AND FINDINGS}

According to historical data, in 1887-1888, newspapers and magazines were scarce in Jizzakh district. In Samarkand region, 62 newspapers were distributed, while in Jizzakh, no newspapers were distributed.

After the establishment of the Republic of Uzbekistan in the former Soviet Union in 1924, the distribution of magazines and newspapers in Jizzakh (the city was part of the Samarkand region and was the center of the city and district) was established. A post of correspondents of the regional newspaper "Zarafshan ovozi" was established in Jizzakh, where local teachers and intellectuals were involved. According to the periodicals of that time, articles by Jizzakh correspondents Hamid Olimjon, Nasrulla Akhundi, Toji Adilov, Bahrom Ibragimov, Narzikul Hasanov and others were published.

According to the May 9, 1925 issue of the "Zarafshon ovozi" newspaper, 41 of the 239 correspondents in the Samarkand region were penmen in Jizzakh. In this regard, the materials prepared by the post of correspondents headed by the youth leader of the Old City Narzikul Yulchibaev were regularly published in regional and national newspapers. Juraboy Ahmadjanov, Yuldash Hoshimov, Sohib Sultanov and Toji Adilov were especially active in this work.

In 1932, the first district newspaper (now “Jizzakh ovozi”) was founded in Jizzakh. The newspaper was originally called The Victory of Socialism. Husan Umarov has been appointed its editor. Talented Mahmud Gazikhanov was soon appointed editor of the newspaper. The first issue of the newspaper was published on June 15, 1932 in the Morozov printing house in Samarkand. In the same year, when the newspaper was founded, its pages covered the lifestyle of workers in Jizzakh, Forish, Gallaaral and Zaamin districts. Until 1940 it was edited by Abdunazar Egamnazarov, Goziev from Asaka, Mamur Zaripov from Jizzakh, Yuldash Hoshimov, Amanmurad Fayzimurodov, Yusuf Yuldashev, Khojam Isroilov from 1962-63, Toji Adilov from 1963, and then Ibrahim Donishev. Journalists such as Nosir Yulchi, Ahmad Ismoilov, Sohib Sultanov have worked as correspondents for the newspaper for several years.

In October 1932, the first printing house was opened in Jizzakh, where the newspaper began to be published. The first working swallows of the printing house were Murtazakul Umarov, Tolib Shodiev, Natasha Parsel, Sabohat Teshaboeva, N. Ahmedova, T. Tukhfatullina and T. Mamadiyorov did a great job in ensuring the regular publication of the newspaper.

Journalists such as Munavvar Tursunov, Haydar Egamberdiev, Lapas Utashev, Karim Fozilov, Yuldash Toshpulatov gathered around the newspaper and regularly published their articles. 
The first works of Hamid Olimjon, Sharof Rashidov, Nazir Safarov, Qodirjon Imamov, Nasrulla Akhundiy, Shukur Sadulla, Jura Ahmadjanov, who left an indelible mark on Uzbek literature and journalism and created a unique creative school, were first published in this newspaper.

In June 1962, the district newspaper was transformed into inter-district newspapers and distributed in Jizzakh, Gallaaral, Zaamin, Forish districts.

\section{CONCLUSION}

In September 1989, due to the territorial unification of the city and district of Jizzakh, the newspaper was transformed into a city and district newspaper. Since 1991, when the country gained independence, the newspaper has been called "Jizzakh ovozi". It currently operates as a socio-political newspaper of the city and district administration.

\section{REFERENCES}

1. History of Jizzakh. H.Haydarov, Q.Usmonov. Teacher Publishing House. Tashkent-2009. P. 132-133.

2. Dedicated to the mirror of life (Jizzakh journalism). Jizzakh regional branch of the Creative Union of Journalists of Uzbekistan., Navruz Publishing House. Tashkent - 2014.

3. "Teacher remembers the journalist", Jizzakh ovozi newspaper, June 26, 1999, 626 (7976).

4. Makhmutaliyevich, K. M., Makhmutaliyevich, K. I., Abdullayevich, Y. A., Qudratovich, A. O., \& Mukhtorjonovich, K. J. (2020). OCTOBER REVOLUTION AND ITS INFLUENCE IN SOCIOPOLITICAL LIFE OF TURKESTAN AT THE BEGINNING OF THE 2OTH CENTURY. Journal of Critical Reviews, 7(6), 115-120.
5. Ermetov, A. A. (2018). FREEDOM OF VENEZUELA AND NEW GRANADA. Interscience, (24-1), 44-45.

6. Ermetov, A. A. (2017). LIBERATION STRUGGLE IN LATIN AMERICAN STATES FROM THE SPANISH EMPIRE. Scientific discussion: issues of sociology, political science, philosophy, history, (5), 12-16.

7. Ermetov, A. A. (2018). From the history of the formation of the workers' and peasants' inspection in Turkestan (1919-1923). In Private and public in the daily life of the Russian population: history and modernity (regional aspect) (pp. 27-31).

8. Ermetov, A. A. (2017). JADIDISM AND THEIR INFLUENCE ON SOCIO-POLITICAL AND CULTURAL LIFE IN THE TURKESTAN REGION. In Young Scientist: Challenges and Perspectives (P. 216-221).

9. Makhmutaliyevich, K. M., Makhmutaliyevich, K. I., Abdullayevich, Y. A., Qudratovich, A. O., \& Mukhtorjonovich, K. J. (2020). OCTOBER REVOLUTION AND ITS INFLUENCE IN SOCIOPOLITICAL LIFE OF TURKESTAN AT THE BEGINNING OF THE 2OTH CENTURY. Journal of Critical Reviews, 7(6), 115-120.

10. Ерметов, А. А. (2017). ОСВОБОДИТЕЛЬНАЯ БОРЬБА В ЛАТИНОАМЕРИКАНСКИХ ГОСУДАРСТВАХ ОТ ИСПАНСКОЙ ИМПЕРИИ. Научная дискуссия: вопросы социологии, политологии, философии, истории, (5), 12-16.

11. Orifjonova, G. R. Q. (2019). Ethnographic collections of museums in Uzbekistan: samples of copper-embossing art. Muzeológia a kultúrne dedičstvo, 7(1), 235-240.

12. Orifjonova, G. R. Q. (2019). Ethnographic collections of museums in Uzbekistan: samples of copper-embossing art. Muzeológia a kultúrne dedičstvo, 7(1), 235-240. 
CURRENT RESEARCH JOURNAL OF HISTORY

(ISSN -2767-472X)

VOLUME 03 ISSUE 01 Pages: 30-33

SJIF IMPACT FACTOR (2021: 5. 505)

OCLC- 1243560778 METADATA IF - 6.458

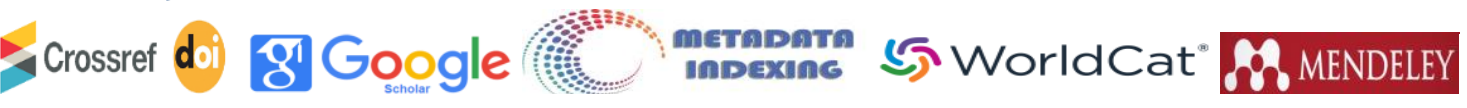

Publisher: Master Journals

13. Khasanov, A. (2016). About several infrastructure constructions of the Great Silk Road. Int'l J Innov Sci Eng Technol, 3(6), 295299. 